\title{
An Atmospheric Tritium Release Database for Model Comparisons
}

by

C. E. Murphy Jr.

Westinghouse Savannah River Company

Savannah River Site

Aiken, South Carolina 29808

G. R. Wortham

This paper was prepared in connection with work done under the above contract number with the U.S. Department of Energy. By acceptance of this paper, the publisher and/or recipient acknowledges the U.S. Government's right to retain a nonexclusive, royalty-free license in and to any copyright covering this paper, along with the right to reproduce and to authorize others to reproduce all or part of the copyrighted paper. 


\section{AN ATMOSPHERIC TRITIUM RELEASE DATABASE FOR MODEL COMPARISONS (U)}

Charles E. Murphy Jr. and G.R. Wortham

Publication Date: January 9, 1995

Revision Date: $\quad$ September 15, 1997

Approved By: D.B. Moore-Shedrow, Manager

Environmental Sciences and Technology Department

Savannah River Technology Center

Westinghouse Savannah River Company

Savannah River Site

Aiken, SC 29808

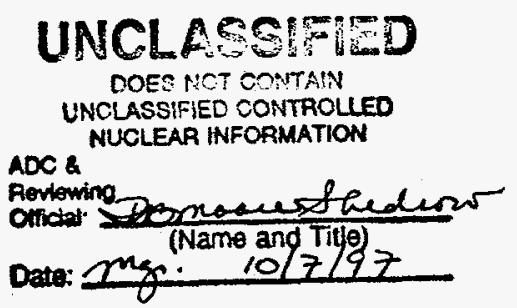




\section{DISCLAIMER}

This report was prepared as an account of work sponsored by an agency of the United States Government. Neither the United States Government nor any agency thereof, nor any of their employees, makes any warranty, express or implied, or assumes any legal liability or responsibility for the accuracy, completeness, or usefulness of any information, apparatus, product, or process disclosed, or represents that its use would not infringe privately owned rights. Reference herein to any specific commercial product, process, or service by trade name, trademark, manufacturer, or otherwise does not necessarily constitute or imply its endorsement, recommendation, or favoring by the United States Government or any agency thereof. The views and opinions of authors expressed herein do not necessarily state or reflect those of the United States Government or any agency thereof.

This report has been reproduced directly from the best available copy.

Available to DOE and DOE contractors from the Office of Scientific and Technical Information, P.O. Box 62, Oak Ridge, TN 37831; prices available from (615) 576-8401.

Available to the public from the National Technical Information Service, U.S. Department of Commerce; 5285 Port Royal Road, Springfield, VA 22161. 


\section{DISCLAmexR}

Portions of this docoment may be illegible in electronic image products. Images are produced from the best available original docoment 
A database of vegetation, soil, and air tritium concentrations at gridded coordinate locations following nine accidental atmospheric releases is described. The concentration data is supported by climatological data taken during and immediately after the releases. In six cases, the release data is supplemented with meteorological data taken at seven towers scattered throughout the immediate area of the releases and data from a single television tower instrumented at eight heights. While none of the releases caused a significant dose to the public, the data collected is valuable for comparison with the results of tritium transport models used for risk assessment. The largest, potential off-site dose from any of the releases was calculated to be $1.6 \mathrm{mrem}$. The population dose from this same release was 46 person-rem which represents $0.04 \%$ of the natural background radiation dose to the population in the path of the release. 


\section{CONTENTS}

ABSTRACT

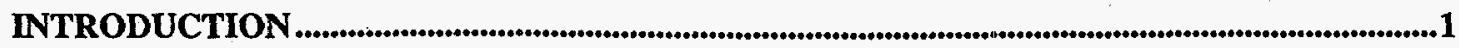

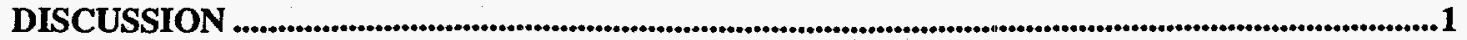

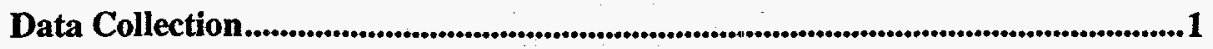

Stack Measurements .......................................................................2

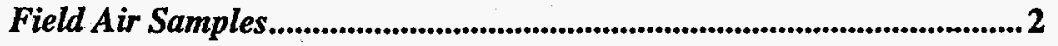

Vegetation Samples....................................................................2

Other Samples ...............................................................................................2

Description of Atmospheric Tritium Release ........................................................2

May 2, 1974 ......................................................................................2

December 31, 1975..........................................................................3

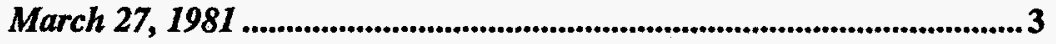

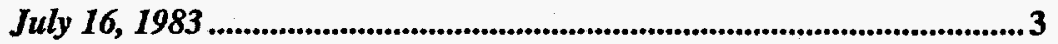

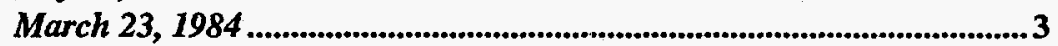

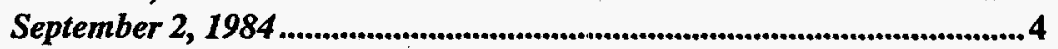

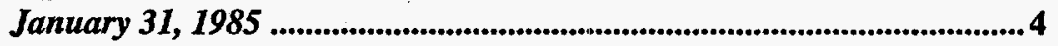

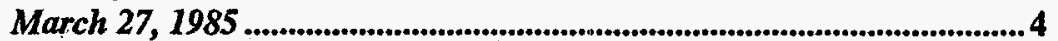

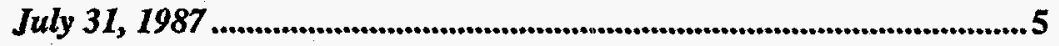

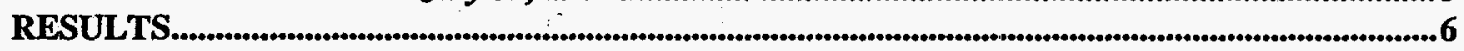

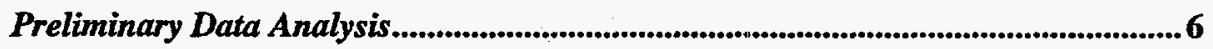

Environmental Tritium Database ........................................................................... 7

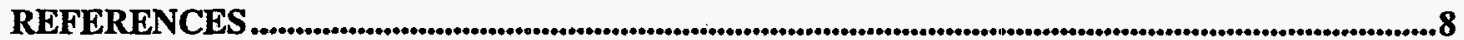

APPENDIX A GRAPHICAL DESCRIPTION OF DATA TYPES

ATTACHMENT: DATABASE OPTICAL DISK 


\section{LIST OF FIGURES}

1. The Maximum Tritiated Water Content of Vegetation Leaves Collected at Approximately $40 \mathrm{~km}$ from the Source of the Release Compared to Estimates Calculated from Exposure to Tritiated Water Vapor for Each Release

A-1 The wind direction during and following the tritium release of

March 27, 1981. Zero azimuth (degrees) is North.

A-2 The wind speed and standard deviation of the azimuth and elevation

angles during and following the tritium release of March 27, 1981

Figure A-3 Fifteen minute average temperature (only a single profiles every two hours are displayed) during and after the tritium release of March 27, 1981.

Figure A-4 Fifteen minute average wind speed (only a single profiles every two hours are displayed) during and after the tritium release of March 27, 1981.

Figure A-5 Fifteen minute average standard deviation of the wind azimuth (only single profiles every two hours are displayed) during and after the tritium release of March 27, 1981.

Figure A-6 Fifteen minute average standard deviation of the wind elevation angle (only single profiles every two hours are displayed) during and after the tritium release of March 27, 1981.

Figure A-7 Vegetative sampling locations following the tritium release of May 2, 1974.

Figure A-8 Vegetative sampling locations following the tritium release of December 31, 1975 15

Figure A-9 Vegetative sampling locations following the tritium release of March 27, 1981. .16

Figure A-10 Vegetative sampling locations following the tritium release of July 16,1983 17

Figure A-11 Vegetative sampling locations following the tritium release of March 23, 1984. 18

Figure A-12 Vegetative sampling locations following the tritium release of March 27, 1985.

Figure A-13 Vegetative sampling locations following the tritium release of January 31,1985 .

Figure A-14 Vegetative and air sampling locations following the tritium release of July 31,1987

\section{LIST OF TABLES}

1. Summary of Tritium Release Characteristics. .4

2. Maximum Environmental Concentrations Following Tritium Releases, $\mathrm{pCi} / \mathrm{mL}$ 


\title{
AN ATMOSPHERIC TRITIUM RELEASE DATABASE FOR MODEL COMPARISONS
}

\author{
By Charles E. Murphy Jr. and G.R. Wortham \\ Westinghouse Savannah River Company \\ Savannah River Site \\ Aiken, SC 29808
}

\begin{abstract}
A database of vegetation, soil, and air tritium concentrations at gridded coordinate locations following nine accidental atmospheric release is described. While none of the releases caused a significant dose to the public, the data collected are valuable for comparison with the results of tritium transport models used for risk assessment. The largest, potential, individual off-site dose from any of the releases was calculated to be $1.6 \mathrm{mrem}$. The population dose from this same release was 46 person-rem which represents $0.04 \%$ of the natural background radiation dose to the population in the path of the release.
\end{abstract}

\section{INTRODUCTION}

This paper will describe a database made up of environmental tritium concentrations measurements after nine atmospheric releases at the Savannah River Site (SRS). The database was assembled to provide environmental scientists with data which can be used in verifying the tritium transport and cycling computer codes that are used in assessing the potential effects from inadvertent releases from tritium handling facilities. This effort was stimulated by the new interest in assessing tritium effects from fusion reactors. ${ }^{1}$ The information should also be of value to the Department of Energy's New Production Reactors Program. 2

The Savannah River Site is a U.S. Department of Energy facility, near Aiken, S.C. which produces and processes tritium for National Defense needs. During the 35 years of tritium production, beginning in 1953, there have been releases of tritium from the five heavy water production reactors and the tritium processing facilities. These releases have been documented in the Annual Monitoring Reports and

\section{DISCUSSION}

\section{Data Collection}

The available technology and methodology for making measurements after detection of a tritium release have evolved over the period from the
Summarized in -a recent assessment of SRS releases. ${ }^{3}$ During this period there have been chronic releases related to normal manufacturing of tritium which have led to a background tritium concentration which decreases with distance from the sources of release. There have also been short-term releases from inadvertent process failures and leaks which have led to short-term increases in the tritium concentration in the environment in the path of the releases. It is these latter releases that will be documented here.

None of the releases caused a significant dose to the public. The largest, potential, individual offsite dose from any of the releases was calculated to be $1.6 \mathrm{mrem}$. The population dose from this same release was 46 person-rem which represents $0.04 \%$ of the natural background radiation dose to the population in the path of the release.

All of the releases documented here entered the environment from a 60-meter, tritium-facility stack. The composition of the releases varied from nearly $100 \%$ tritiated hydrogen to $100 \%$ tritiated water.

first release in 1974 until the present. However, the chronology of events has remained the same. Initial measurements are made in the 60-meter stack where all of the releases entered the environment. After the release has been verified, 
sampling crews are sent to the field. Field measurement methodology was originally based on experience gained from measurement of chronic releases. Typically samples were taken of vegetation, air, surface water, and milk.

\section{Stack Measurements}

The tritium concentration of a flowing sample of stack gas is measured with a Kanne ionization. chamber. The amount of tritium in the release is calculated by multiplying the air flow in the stack by the integral, average tritium concentration during the time interval of the release.

In recent years the stack sampling system has been modified to allow measurement of the chemical form of tritium in a release. Two Kanne chambers are used. In one chamber the moisture is removed from the air before measurement. In the other chamber the air is not dried. The amount of tritiated water in the release is measured by subtracting the tritium remaining in the dried air from the total tritium measured by the Kanne chamber receiving undried air. Under SRS conditions most of the tritium measured in the chamber receiving dry air is in the form of molecular hydrogen.

\section{Field Air Samples}

The portable, field tritium air sampler used at SRS uses molecular sieve which removes a sample of air moisture followed by a second sieve trap where tritiated hydrogen is oxidized and collected by palladium coated sieve. Air flow rates and sampling periods are carefully set before placement in the field. The water from the sieve is collected after heating under vacuum. The tritium is counted by proportional counting after dissociation of the water to hydrogen.

One of the initial uses of this sampler was during the May 1974 release when a sampling crew was

\section{Description of Atmospheric Tritium Releases}

The following section will provide a brief description of the characteristics of the nine atmospheric releases included in the database. Because of the complex factors determining the spread and uptake of tritium by vegetation and soil from a short-term release, it is necessary to treat each release as a special case. able to catch up with the plume and measure the concentration of water vapor and hydrogen in the release. SRS continues to rely on this technique and the number of samplers available for deployment has increased. Only following the July, 1987 release, when eighteen samplers were used, is there enough air monitoring data to be useful for modeling studies.

\section{Vegetation Samples}

Vegetation samples are cut and stored in plasstic bags. The samples are processed as soon as practical after collection. The samples are vacuum distilled to remove an aliquot of water. The water is then counted by liquid scintillation.

Vegetation sampling does not require special field equipment and can be done quickly by field crews. Samples often number in the hundreds and transects across a plume path can have fifty samples. Vegetation sampling has proved to be very effective in post-release evaluation of the plume path and will provide the majority of data in the database described here.

\section{Other Samples}

Milk samples are vacuum distilled and the water is counted by liquid scintillation. Milk samples are made only in those cases when the release of the plume passes over a farm where cows are present. Surface water samples are directly counted by liquid scintillation unless they are discolored, in which case they are vacuum distilled. After a few of the releases, the tritiated water content of the soil was measured. Soil samples were vacuum distilled in the same manner as vegetation samples. Soil samples were taken because of evidence that tritiated hydrogen is oxidized by soil microorganisms. 4.5

A valve failure resulted in a $479,000-\mathrm{Ci}$ release from a $60-\mathrm{m}$ stack located in the Separations Area. The release occurred over a 4-min period beginning at 0755 hours eastern standard time (EST). The tritium form was estimated to be primarily tritiated hydrogen gas with less than $1 \%$ tritiated water.

May 2,1974. 
At the time of the release, light winds carried the tritium in a northeasterly direction (azimuth 210 225 degrees) at 6.4 to $9.7 \mathrm{~km} / \mathrm{hr}$. Cloud cover at Bush Field in Augusta, GA, was $90 \%-100 \%$. The atmospheric stability was judged to be neutral. The trajectory of the release carried the tritium north of Columbia, SC, beyond which point it was difficult to predict because of complex weather patterns.

Extensive measurements were made of the tritiated water content of vegetation, soils, and surface water. A single air sample collected about $5 \mathrm{hr}$ after the release had a $30-\mathrm{mm}$ average concentration of $390,000 \mathrm{pCi} / \mathrm{m}^{3}$, of which less than $1 \%$ was in the form of tritiated water. The highest vegetation, surface water, and soil water concentrations were $4630,10,000$, and $138 \mathrm{pCi} /$ $\mathrm{mL}$, respectively. Milk collected from a beef cow was found to have an elevated tritium concentration of $375 \mathrm{pCi} / \mathrm{mL}$.

\section{December 31,1975}

At 2000 hours EST, $182,000 \mathrm{Ci}$ of tritium gas was released from a stack in the Separations Area. Ninety percent of the tritium was released in the first $1.5 \mathrm{~min}$. Air samples indicated that $0.6 \%$ of the release was in the form of tritiated water with the rest in the hydrogen form.

The cloud cover was about $30 \%$ and the wind speed $35 \mathrm{~km} / \mathrm{hr}$ at the time of the release. The atmospheric stability was neutral. The wind carried the release in an easterly direction (azimuth 270-289 degrees). The trajectory of the release carried the tritium north of Charleston, SC, where it passed over the ocean between 0500 and 0600 hours on January 1, 1976.

Maximum air moisture, surface water, and soil tritium concentrations were 687,27 , and 242 $\mathrm{Ci} / \mathrm{mL}$, respectively, Air, water, and milk samples collected after the release were within the values routinely measured at other times.

\section{March 27, 1981}

At approximately 0845 hours EST, 33,000 Ci of tritium were released to the atmosphere from a separations area processing facility. The duration of the release was about $2.5 \mathrm{hr}$. Analyses of stack samples taken during the incident indicated that $99.7 \%$ of the tritium was released as tritiated water vapor.
The sky was sunny during the day, with scattered cumulus clouds forming in the afternoon. The temperature was between 240 and $27^{\circ} \mathrm{C}$. The surface wind at the time of the release was blowing at $18 \mathrm{~km} / \mathrm{hr}$ toward the east. Later in the day this increased to 21 to $26 \mathrm{~km} / \mathrm{hr}$. The trajectory carried the release northeastward where it crossed the coastline at approximately the North Carolina-South Carolina boundary. .

Maximum tritiated water concentrations were 270,9 , and $39 \mathrm{pCi} / \mathrm{mL}$ for vegetation, surface water, and soil water samples, respectively, collected outside the boundary of SRS. A vegetation sample inside the SRS boundary was found to have a tritiated water concentration of $4860 \mathrm{pCi} / \mathrm{mL}$. Milk and foodstuff samples were within the values measured at other times.

\section{July 16,1983}

At 2213 hours EST, $56,000 \mathrm{Ci}$ of tritium were released from the Separations Area. The release took place over a period of approximately 3 minutes. Analysis of samples of the released gases indicated that about $1 \%$ of the release was tritiated water vapor and the remaining $99 \%$ was in the hydrogen form.

The sky was $75 \%$ to $100 \%$ covered with clouds at the time of the release, with rain and thundershowers early in the evening. The cloud cover dissipated by 0200 hours of the following day. Surface winds were $18 \mathrm{~km} / \mathrm{hr}$ around the time of the release, blowing toward the northeast. The trajectory carried the release offshore north of Charleston, SC.

Maximum vegetation, surface water, and rainwater tritium concentrations were 150,23 , and $18 \mathrm{pCi} / \mathrm{mL}$, respectively. Milk and air moisture samples were within the concentration range routinely measured in samples in the vicinity of SRS.

\section{March 23, 1984}

At 0440 EST, a leak in a process line led to a release of $7500 \mathrm{Ci}$ from a stack in the Separation Area. The majority of the release occurred in the first $2 \mathrm{hr}$ and $20 \mathrm{~mm}$. Approximately $70 \%$ of the release was in the tritiated water vapor form; the remaining $30 \%$ was in the hydrogen form. 
During the morning of the release, the winds were blowing toward the east-southeast (azimuth of 280 degrees) at $21 \mathrm{~km} / \mathrm{hr}$. Skies were clear with a $10 \%$ cloud cover. There was a low-level inversion at the time of the release, indicating stable atmospheric conditions. The inversion dissipated by 0930 hours, and unstable atmospheric condition prevailed from that time forward. The release trajectory moved to the south-southeast for the first 2 hours then swung to the southeast for the next 8 hours before turning to the northeast and moving over the ocean near Charleston, SC.

Maximum vegetation and surface water tritiated water concentrations were 1380 and $120 \mathrm{pCi} / \mathrm{mL}$, respectively. Two sampling teams measured tritium forms in atmospheric samples. The highest concentration was found to be 6170 $\mathrm{pCi} / \mathrm{m}^{3}$, with about $90 \%$ of the sample in the water vapor form. The maximum tritium concentration in milk was $69 \mathrm{pCi} / \mathrm{mL}$.

September 2, 1984

Beginning at 1900 hours EST, a release of $57,900 \mathrm{Ci}$ of tritium occurred from a stack in the Separations Area. Approximately $43,800 \mathrm{Ci}$ were released in the first 5 hours of the period, with the remainder slowly entering the environment over the next 5 days. The release consisted of $99 \%$ tritiated water vapor.

At the beginning of the release, the wind was blowing in the direction of Aiken, SC (azimuth 170 degrees). The wind speed remained steady at $16 \mathrm{~km} / \mathrm{hr}$ during the first 5 hours after the release. The wind later shifted toward the east carrying the tritium near Lexington, SC. Temperature profiles from the instruments on the WJBF television tower indicated an inversion existed, and the stable atmospheric conditions kept the plume in a narrow band as it moved away from the source.

Sampling teams measured atmospheric tritium along the path of the release. Because the release path was narrow, it was difficult to obtain samples in the center of the release. The highest tritium concentration measured was 15,871 $\mathrm{pCi} / \mathrm{m}^{3}$ at Blythewood, $\mathrm{SC}$, about $124 \mathrm{~km}$ from the release source. Vegetation samples from this location indicated that this may have been very close to the center of the path. Vegetation and milk samples were collected by SRS and South
Carolina Department of Health and Environmental Control (SCDHEC) sampling teams. The highest concentration of tritiated water in vegetation was $9800 \mathrm{pCi} / \mathrm{mL}$, measured at a location $40 \mathrm{~km}$ from the release point. The highest concentration near the SRS boundary was $2500 \mathrm{pCi} / \mathrm{mL}$. The highest concentration found in milk was $47 \mathrm{pCi} / \mathrm{mL}$ near Windsor, $\mathrm{SC}$.

\section{January 31,1985}

A total of $9285 \mathrm{Ci}$ of tritium was released from a stack in the Separations Area. The release took place from 1400 to 1700 hours EST. The majority of the tritium, $7400 \mathrm{Ci}$, was released in the first $15 \mathrm{~mm}$. Of the total release, $54 \%$ was in the tritiated water form and the remaining $46 \%$ was in the hydrogen form.

At the time of the release, the wind was blowing toward the north-northeast at $21 \mathrm{~km} / \mathrm{hr}$. The cloud cover at Bush Field, Augusta, GA, was $100 \%$. The atmospheric stability ranged from mildly unstable to neutral during the release period. The release trajectory passed Windsor, SC, and could be tracked, with substantially decreased concentration, to the southwest of Columbia, SC.

Measurements were taken of vegetation, surface water, and milk following the release. The highest concentrations were, respectively, 7600 , 140 , and $4.3 \mathrm{pCi} / \mathrm{mL}$. Milk tritium concentrations were within the concentrations normally measured by the SRS Environmental Survey. The air tritiated water vapor content at Windsor was measured at $576 \mathrm{pCi} / \mathrm{m}^{3}$.

\section{March 27,1985}

The release, from the Separations Area stack, began at 1353 hours EST and averaged about 90 $\mathrm{Ci} /$ minute until 1830 hours when the released ceased. Stack sampling indicated that of the $19,422 \mathrm{Ci}$ in the release, $99.9 \%$ was tritiated water vapor.

Meteorological observations at Bush Field, Augusta, GA, showed that the cloud cover was $70 \%$ and the wind speed from 16 to $23 \mathrm{~km} / \mathrm{hr}$. The atmospheric stability varied from slightly unstable to neutral during the period when the release was passing though South Carolina. The trajectory of the release initially carried the tritium in a northeasterly direction, passing southeast of Columbia, SC. The release crossed 
into North Carolina before moving over the ocean.

The highest vegetation and surface water concentrations measured within the SRS boundary were 61,800 and $384 \mathrm{pCi} / \mathrm{mL}$, respectively. These values had decreased to 971 and $1.4 \mathrm{pCi} / \mathrm{mL}$ by the time the tritium reached the SRS boundary. Milk samples collected after the release showed levels that were within the range normally measured by SRS surveys. Air sampling was done by the TRAC mobile laboratory and sampling teams with mobile tritium forms samplers. The highest concentration of tritium measured in the air was $21,689 \mathrm{pCi} / \mathrm{m}^{3}$. The tritium form of this sample was greater than $99 \%$ tritiated water vapor.

July 31,1987

The release occurred from the Separations Area stack between 0817 and 0855 hours EST. The estimated total amount released, based on the tritium forms monitor, was $172,000 \mathrm{Ci}$. The oxide fraction, based on the stack air monitor, was $2.7 \%$. The remaining $97.8 \%$ was in the hydrogen form.

The weather on July 31 was characterized by very weak wind $(8 \mathrm{~km} / \mathrm{hr})$ blowing toward the northeast and very unstable atmospheric temperature stratification. The height of the atmospheric mixing zone was $200 \mathrm{~m}$ at 0830 hours and $2200 \mathrm{~m}$ by mid afternoon. Afternoon showers and the associated wind further dispersed the tritium as it moved beyond
Blackville, SC. Traces of the tritium were found from Swansea to Orangeburg, SC.

SRS Environmental Monitoring teams collected vegetation, water, and milk samples on and off the site, while SCDHEC collected vegetation samples offsite. The highest concentrations were 5760 and $47 \mathrm{pCi} / \mathrm{mL}$ for vegetation and surface water, respectively. The concentration in milk was within the range normally found by SRS Environmental Surveys. Extensive measuremënts were made of the air concentration with tritium forms samplers. The highest concentration was about 12.4 million $\mathrm{pCi} / \mathrm{m}^{3}$. Samples collected near the release point showed a fairly uniform concentration of tritiated water vapor, averaging around $3 \%$. Farther from the SRS boundary, the fraction of tritiated water vapor ranged from $0.3 \%$ to $84 \%$ (in a sample with a total tritium concentration of $3300 \mathrm{pCi} / \mathrm{m}^{3}$ ). The separation of the forms of tritium is thought to be the result of differences in uptake at the surface or from washout of tritium in the vicinity of the rain storms.

Table 1 summarizes the characteristics of each release and the meteorological conditions immediatelly after each release described above. The releases have taken place under a wide range of meteorological conditions, during different seasons of the year and beginning at different times of the day.

Table 1. Summary of Tritium Release Characteristics.

\begin{tabular}{|c|c|c|c|c|c|c|}
\hline Date & Time & $\begin{array}{l}\text { Release } \\
\text { Curies }\end{array}$ & \% HTO & $\begin{array}{c}\text { HTO } \\
\text { Curies }\end{array}$ & $\begin{array}{c}\text { Wind } \\
\text { Speed, } \mathrm{m} / \mathrm{s}\end{array}$ & $\begin{array}{c}\text { Atmospheric } \\
\text { Stability Class }\end{array}$ \\
\hline $5 / 2 / 74$ & 755 & 479000 & 1 & 4790 & 3 & Neutral \\
\hline $12 / 31 / 75$ & 2000 & 182000 & 0.6 & 1092 & 10 & Neutral \\
\hline $3 / 27 / 81$ & 845 & 32934 & 100 & 32934 & 7 & Unstable \\
\hline $7 / 16 / 83$ & 2013 & 56000 & 1 & 560 & 6 & Neutral \\
\hline $3 / 23 / 84$ & 440 & 7500 & 70 & 5250 & 5 & Stable \\
\hline $9 / 2 / 84$ & 1900 & 43800 & 100 & 43800 & 5 & Stable \\
\hline $1 / 31 / 85$ & 1400 & 9300 & 50 & 4650 & 5 & Neutral \\
\hline $3 / 27 / 85$ & 1353 & 19422 & 99.9 & 19403 & 7 & Neutral \\
\hline $7 / 31 / 87$ & 855 & 172000 & 2.7 & 4644 & 2 & Unstable \\
\hline
\end{tabular}

\section{RESULTS}

Preliminary Data Analysis 
A simple guassian model was compared to the maximum vegetation concentration at each transect of the release plumes where enough data points existed to indicate the maximum location. 6 The maximum concentrations in the vegetation, as well as other environmental media that were not associated with a location are shown in Table 2.
Figure 1 shows the relationship between the maximum tritiated water content at the $40 \mathrm{~km}$ transects and the predictions of the model. The results are very encouraging, in that they indicate that some of the variation in vegetation concentration is accounted for by the meteorology during the releases.

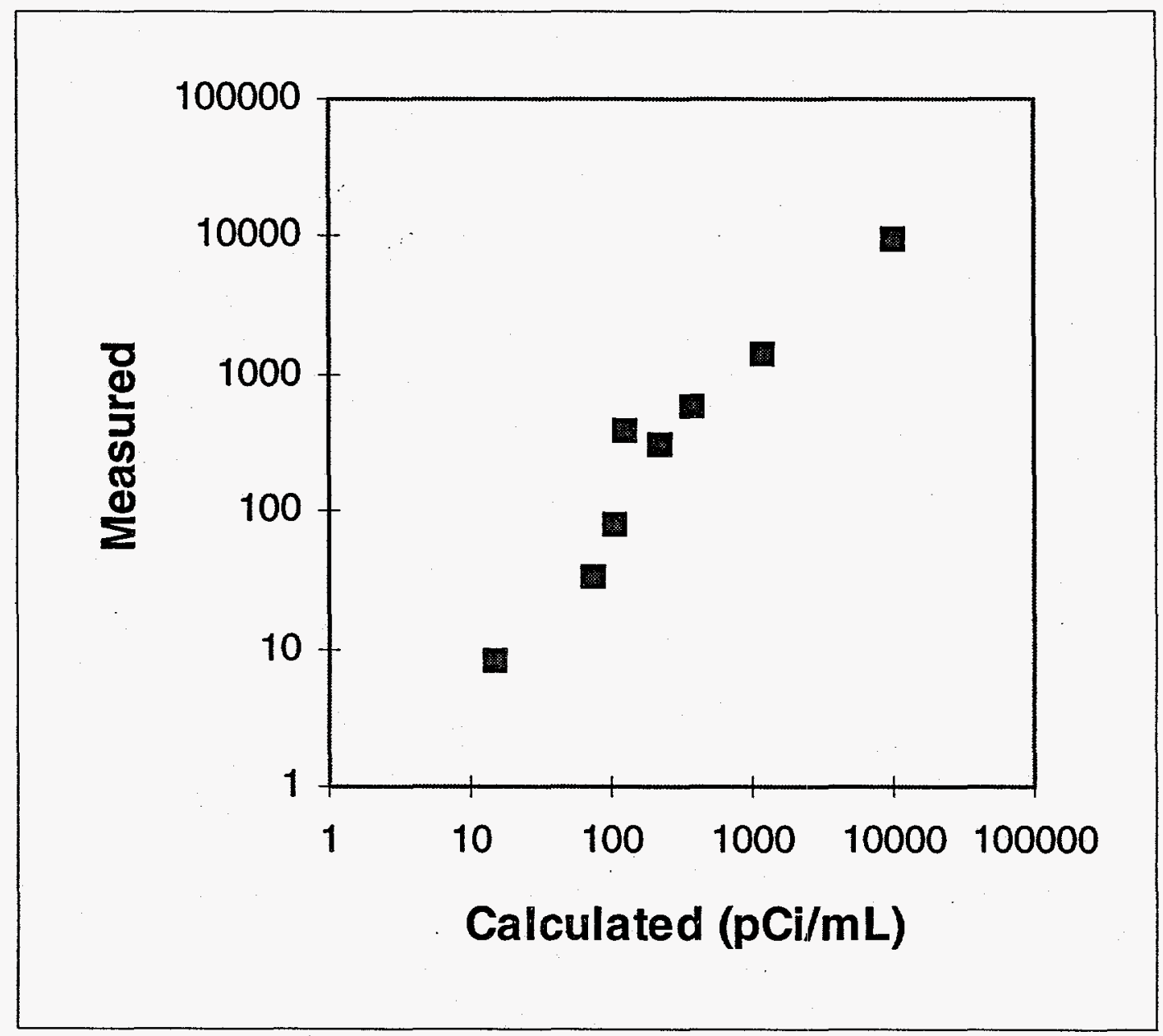

Figure 1. The Maximum Tritiated Water Content of Vegetation Leaves Collected at Approximately $40 \mathrm{~km}$ from the Source of the Release Compared to Estimates Calculated from Exposure to Tritiated Water Vapor for Each Release 
Table 2. Maximum Environmental Concentrations Following Tritium Releases, pCi/mL.

\begin{tabular}{|c|c|c|c|c|c|c|c|}
\hline \multirow[b]{2}{*}{ Date } & \multirow[b]{2}{*}{$\underline{\text { On Site }}$} & \multicolumn{3}{|c|}{ Vegetation } & \multirow{2}{*}{$\begin{array}{c}\text { Surface } \\
\text { Water }\end{array}$} & \multirow[b]{2}{*}{ Milk } & \multirow{2}{*}{$\begin{array}{c}\text { Data } \\
\text { Source }\end{array}$} \\
\hline & & Perimeter & $40 \mathrm{~km}$ & $80 \mathrm{~km}$ & & & \\
\hline $5 / 2 / 74$ & 25 & 4630 & 310 & 41 & 138 & 375 & 7 \\
\hline $12 / 31 / 75$ & 687 & 92 & 8 & & 3 & 9 & 8 \\
\hline $3 / 27 / 81$ & 4860 & 270 & & & 9 & 11 & 9 \\
\hline $7 / 16 / 83$ & 150 & 110 & 80 & 27 & 23 & 4 & 10 \\
\hline $3 / 23 / 84$ & 89 & 500 & 1380 & 190 & 120 & 69 & 11 \\
\hline $9 / 2 / 84$ & 500 & 2500 & 9900 & 240 & & 47 & 12 \\
\hline $1 / 31 / 85$ & 7600 & 450 & 380 & 180 & 140 & 2 & 13 \\
\hline $3 / 27 / 85$ & 61800 & 970 & 590 & 143 & 384 & 6 & 13 \\
\hline $7 / 31 / 87$ & 5760 & 4690 & 34 & 8 & 47 & 4 & 14 \\
\hline
\end{tabular}

\section{ENVIRONMENTAL TRITIUM DATABASE}

The database is presented on the accompanying disk. Four file types are included. The field concentration data files include the tritium concentration in vegetation, soil, and/or air collected on the day of the release (unless otherwise indicated). Each concentration value is identified with a location. The location is a universal transverse mercador (UTM) grid location. The units are meters. When available, the counting error of the measurements is included.

The climatology files include lists of the meteorological measurement from the U.S. NOAA weather station at Bushfield Airport in Augusta, GA, the nearest NOAA weather station to the release site. This data is supplemented with an estimate of the solar radiation incident on the release area and an estimate of the atmospheric stability. The solar radiation is derived from the methods described in List ${ }^{17}$, Overcamp ${ }^{18}$, vanWijk and Scholte-Ubing ${ }^{19}$. Cloud cover and sun-earth geometry are the basis of the estimates. The stability class is calculated using the criteria suggested by Turner. 5 The numerical values in the table refer to the Pasquill stability class where the most stable case, Pasquill $F$, is designated by 5 and the most unstable case, Pasquill $A$ is designated by 0 .

The SRS seven tower system data has been put in the form used to calculate puff/plume trajectory and dispersion for the SRS emergency response code. The towers are instrumented with bivanes and cup anemometers. The azimuth, wind speed, standard deviation of the azimuth angle $\left(\sigma_{\mathrm{a}}\right)$ and standard deviation of the elevation angle $\left(\sigma_{e}\right)$ are all based on the a characteristic 15-minute average for the entire SRS site. The values in these files are the mode of the values at the seven towers. The mode removes extreme values which are characteristic of malfunctioning instruments. All data from the seven tower system used in these calculations is from the 60 meter tower height, the same height as the release stack.

The WJBF television tower, nearby but not located at the site, is instrumented with bivanes, cup anemometers and temperature sensors at seven heights from 18 to 304 meters. Fifteen minute averages of temperature, wind speed, azimuth angle, the standard deviation of the azimuth angle and the standard deviation of the elevation angle are provided for each height. Temperature is also given for an adjacent 2 meter tower. In this dataset, data from malfunctioning sensors has been replaced by a zero.

All data are formatted as comma delimited, ASCI files. The first line of the files is a header defining the data in the corresponding columns. Examples of the data are illustrated graphically in the figures in the Appendix. 


\section{REFERENCES}

1. Burnham, C.D., R.M. Brown, G.L Orgram, and F.S. Spencer. An Overview of Experiments at Chalk River. Fusion Technology 24, p 1159 (1988).

2. Murphy, C.E. Jr. The Transport, Dispersion, and Cycling of Tritium in the Environment. WSRC-RP-90-462. Westinghouse Savannah River Company, Aiken, SC, (1990)

3. Murphy, C.E., Jr., L.R. Bauer, D.W. Hayes, W.L. Marter, C.C. Zeigler, D.E. Stephenson, D.D. Hoel, D.M. Hamby, Tritium in the Savannah River Site Environment. WSRC-RP-90-424-1. Westinghouse Savannah River Company. Aiken, SC 29808 (1990)

4. McFarlane, J.C., R.D. Rogers, and D.V. Bradley. Environmental Tritium Oxidation in Surface Soil, Env. Sci. Technol. p590 (1978).

5. Murphy, C.E., Jr., A.L. Boni, and S.P. Tucker. 1976. The Conversion of Gaseous Molecular Tritium to Tritiated Water in Biological Systems, DP- 1422, E.I. du Pont de Nemours \& Co., Savannah River Laboratory, Aiken, SC 29808 (1976).

6. Murphy, C.E., Jr., L.R. Bauer, and D. Hoel. Tritium atmospheric transport and deposition following acute releases Comparisons with simple Transport Models. Fusion Technology 21:489-493 (1992).

7. Marter, W.L. Analysis of Effects of a Tritium Release from the Savannah River Plant, May 2,1974. DP-1369, E.I. du Pont de Nemours \& Co., Savannah River Laboratory, Aiken, SC 29808 (1975).

8. Jacobsen, W. R. Environmental Effects of a Tritium Gas Release From the Savannah River Plant on December 31, 1975. DP1415, E.I. du Pont de Nemours \& Co., Inc., Savannah River Plant, Aiken, SC (1975).
9. Garrett, A.J., EL. Wilhite, and M. R. Buckner. Environmental Effects of a Tritium Re lease from the Savannah River Plant. DP1613. E.I. du Pont de Nemours \& Company, Inc., Savannah River Plant, Aiken, SC 29808 (1981).

10. Garrett, A. J., C. C. Zeigler, D. R. Carver, and D.A. Stevenson Environmental Aspects of a Tritium Release from the Savannah River Plant on July 16,1983. DP- 1672, E.I. du Pont de Nemours \& Co., Savannah River Plant, Aiken, SC 29808 (1983).

11. Evans, AG., D.D. Hoel, and M.V. Kantelo. Environmental Aspects of a Tritium Release from the Savannah River Plant on March 23, 1984. DP-1695, E.I. du Pont de Nemours \& Co., Savannah River Laboratory, Aiken, SC 29808 (1985).

12. Hoel, D. D., R. J. Kurzeja, and A. G. Evans. 3, 1984. WSRC-RP-90-8 14, Westinghouse Savannah River Company, Aiken, SC 29808 (1984).

13. Zeigler, C.C., I. B. Lawrimore, E. M.. Heath. US Department of Energy Savannah River Plant Environmental Report for 1985, DPSPU 86-30-1, E.I. du Pont de Nemours and Co., Aiken, SC 29808 (1985).

14. Kurzeja, R.J., R.W. Taylor, J. Sharma, and L.T. Burckhalter. Environmental Effects of the July 31, 1987 Tritium Release from the Savannah River Plant. DP- 1758, E.I. du Pont de Nemours \& Co., Inc., Savannah River Laboratory, Aiken, SC 29808 (1987).

15. Turner, D.B. Relationships between 24hour mean air quality measurements and meteorological factors in Nashville, Tennessee. J. Air Poll. Cont. Assoc. 11:483489 (1961).

16. Raskob, W. 1993. Description of the New Version 4.0 of the Tritium Model UFOTRI Including User . Guide. Institut fur Neutronenphysik und Reacktortechnik, Projekt Kemfusion, Kernforschungszentrum Karlruhe, Germany, 92 P. 
17. List, R.J. 1966 Smithsonian Meteorological Tables. Smithsonian Institution, Washington, 527p.

18. Overcamp, T. 1982. Climatology of Solar Infrared, and PAR Radiation at the Savannah River Site, S.C., contract report from Clemson University.
19. vanWijk, W.R. and D.W. Scholte-Ubing. 1963 Radiation. in: Physics of Plant Environment. W.R. van Wijk, ed., NorthHolland Publishing Company, Amsterdam, 62-98. 
Appendix A

Graphical Description of Data Types 
Example of Seven Tower Average Statistic

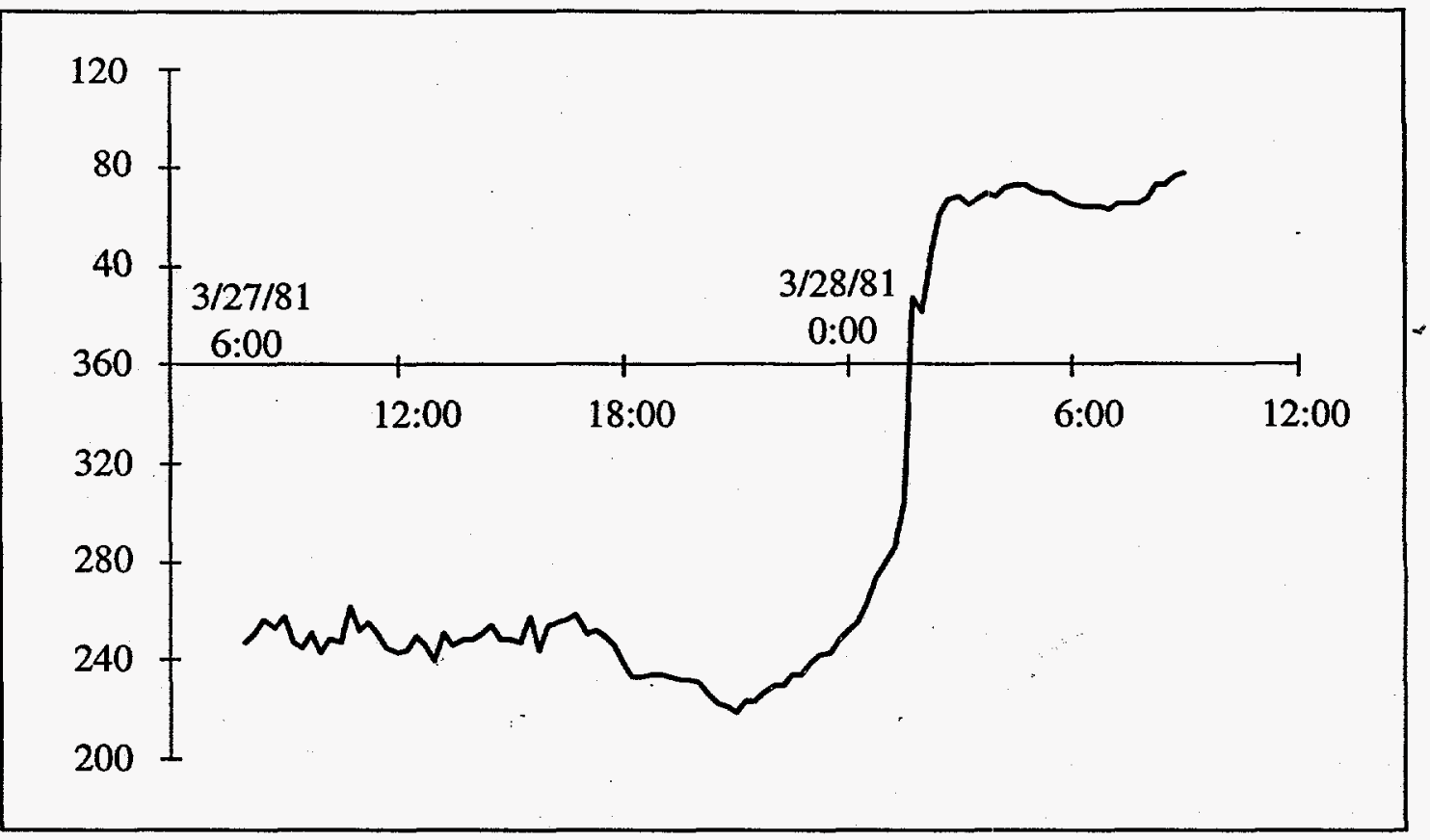

Figure A-1 The wind direction during and following the tritium release of March 27, 1981. Zero azimuth (degrees) is North.

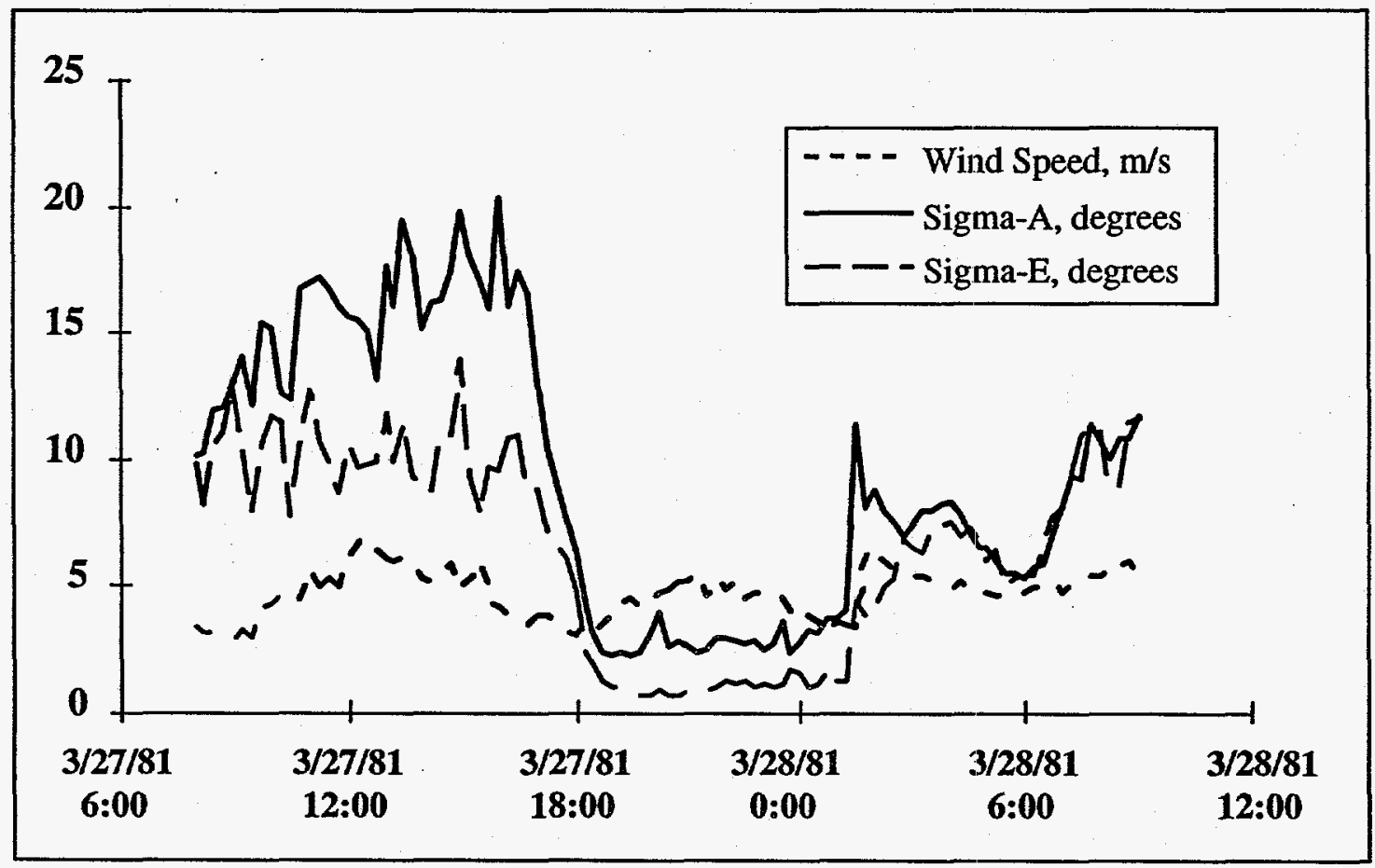

Figure A-2 The wind speed and standard deviation of the azimuth and elevation angles during and following the tritium release of March 27, 1981. 


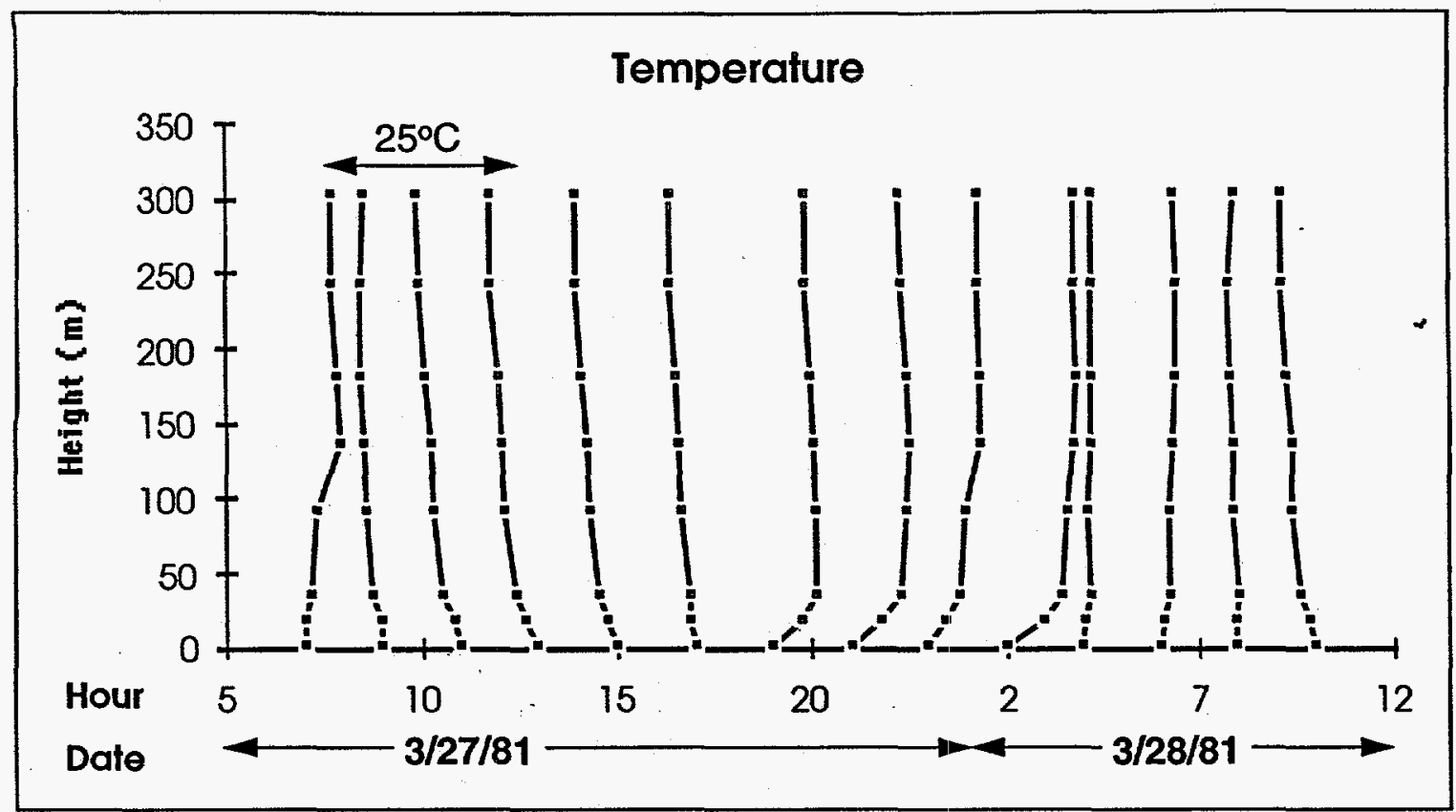

Figure A-3 Fifteen minute average temperature (only a single profiles every two hours are displayed) during and after the tritium release of March 27, 1981.

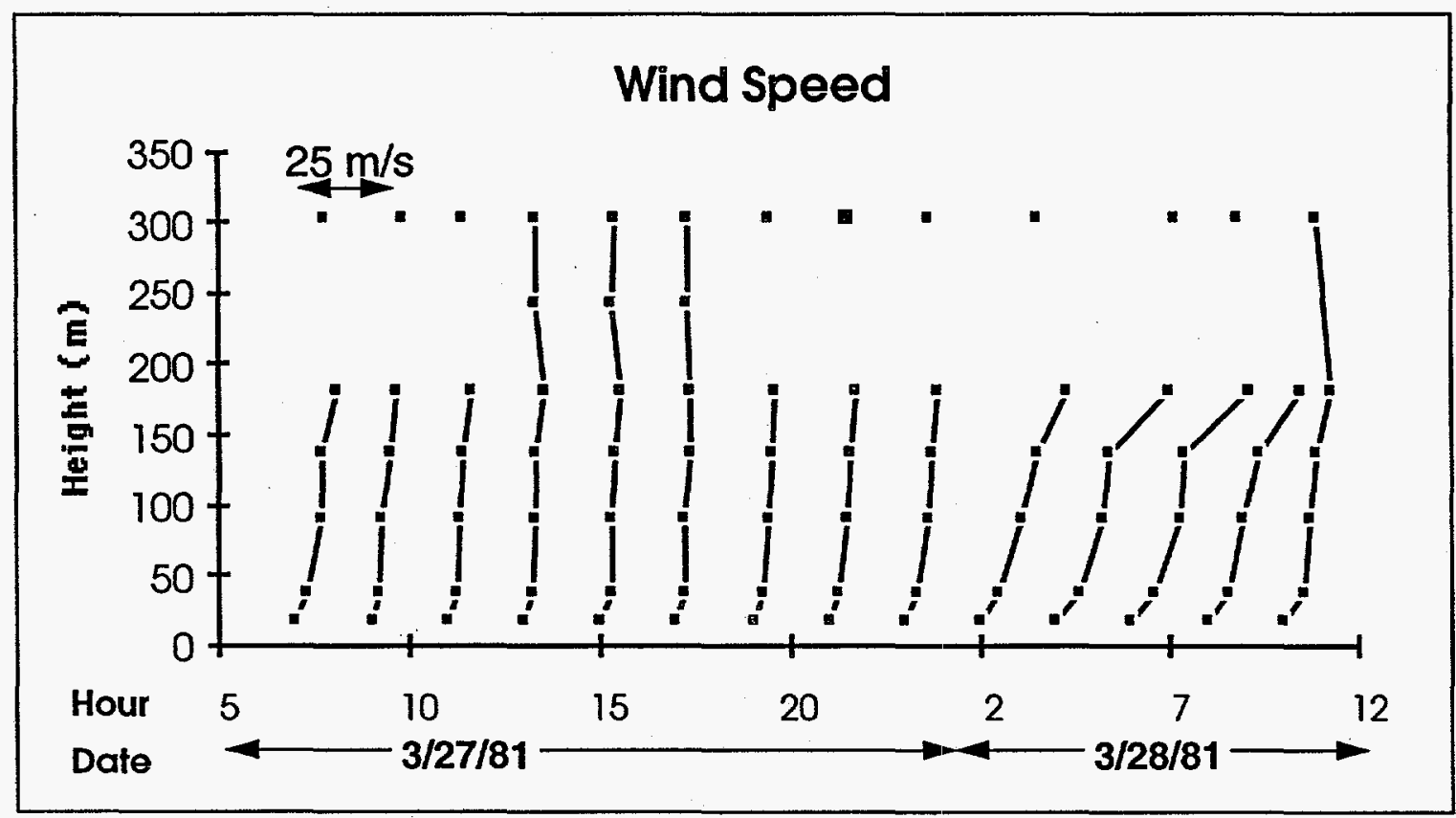

Figure A-4 Fifteen minute average wind speed (only a single profiles every two hours are displayed) during and after the tritium release of March 27, 1981. 


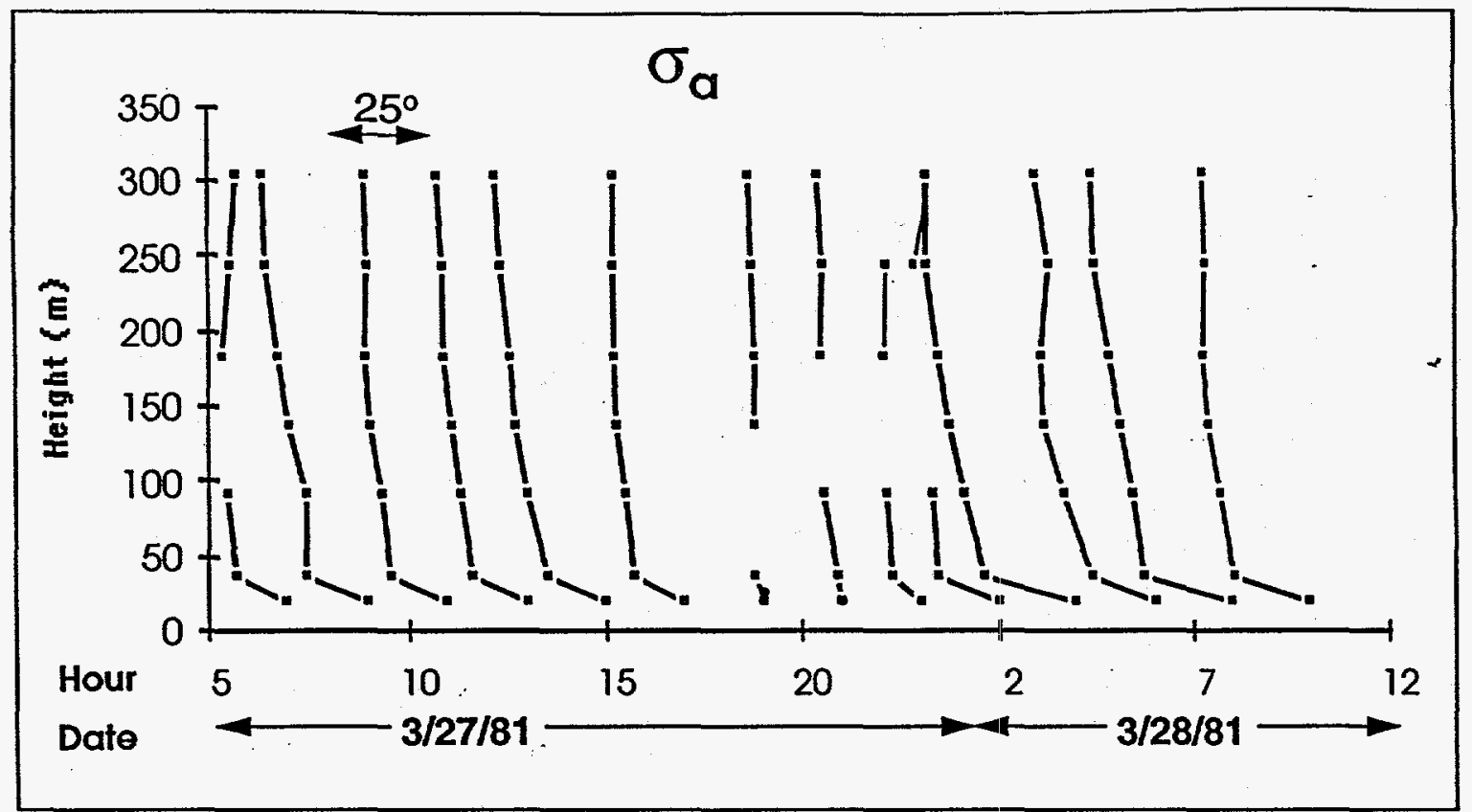

Figure A-5 Fifteen minute average standard deviation of the wind arimuth (only single profiles every two hours are displayed) during and after the tritium release of March 27, 1981.

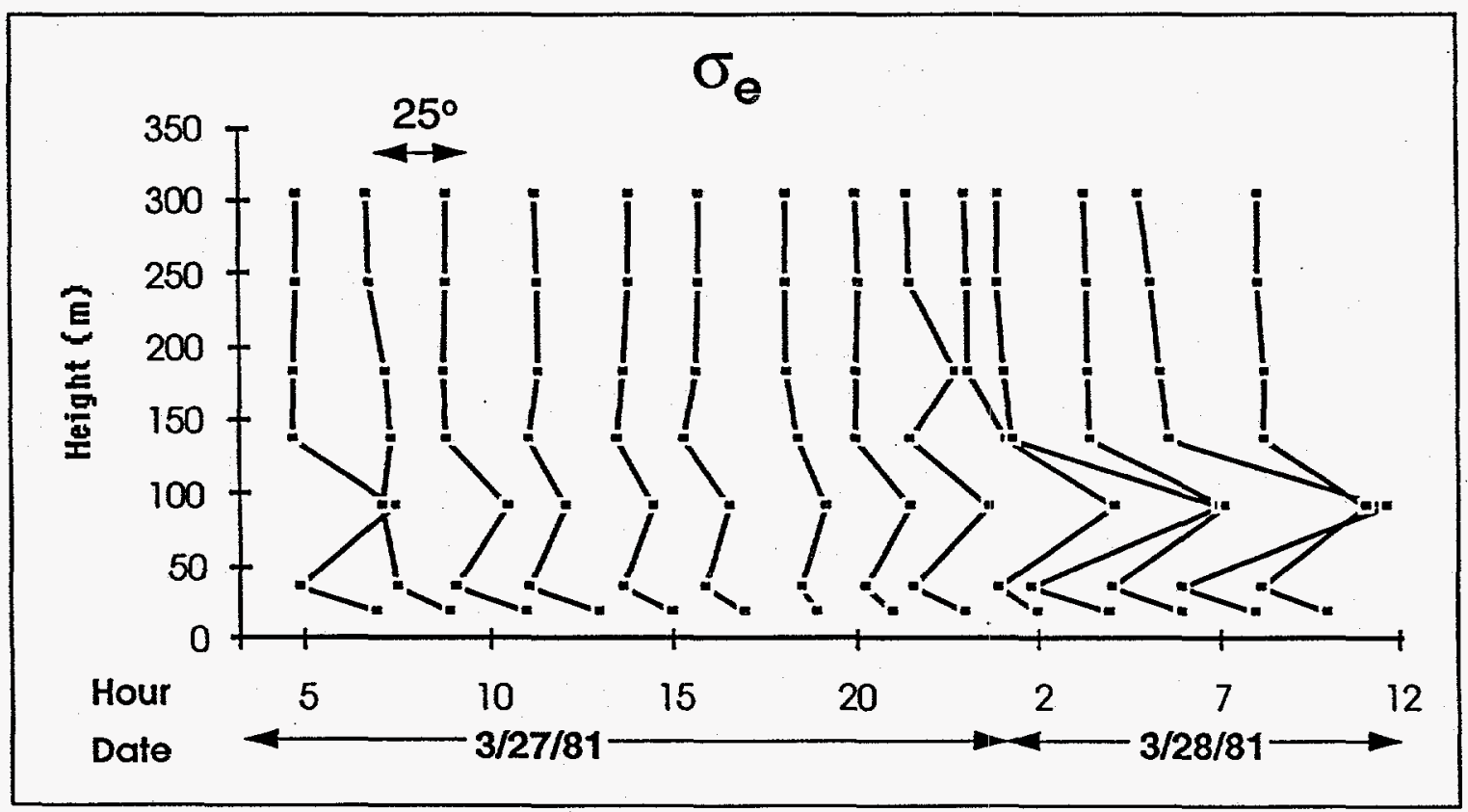

Figure A-6 Fifteen minute average standard deviation of the wind elevation angle (only single profiles every two hours are displayed) during and after the tritium release of March 27, 1981. 


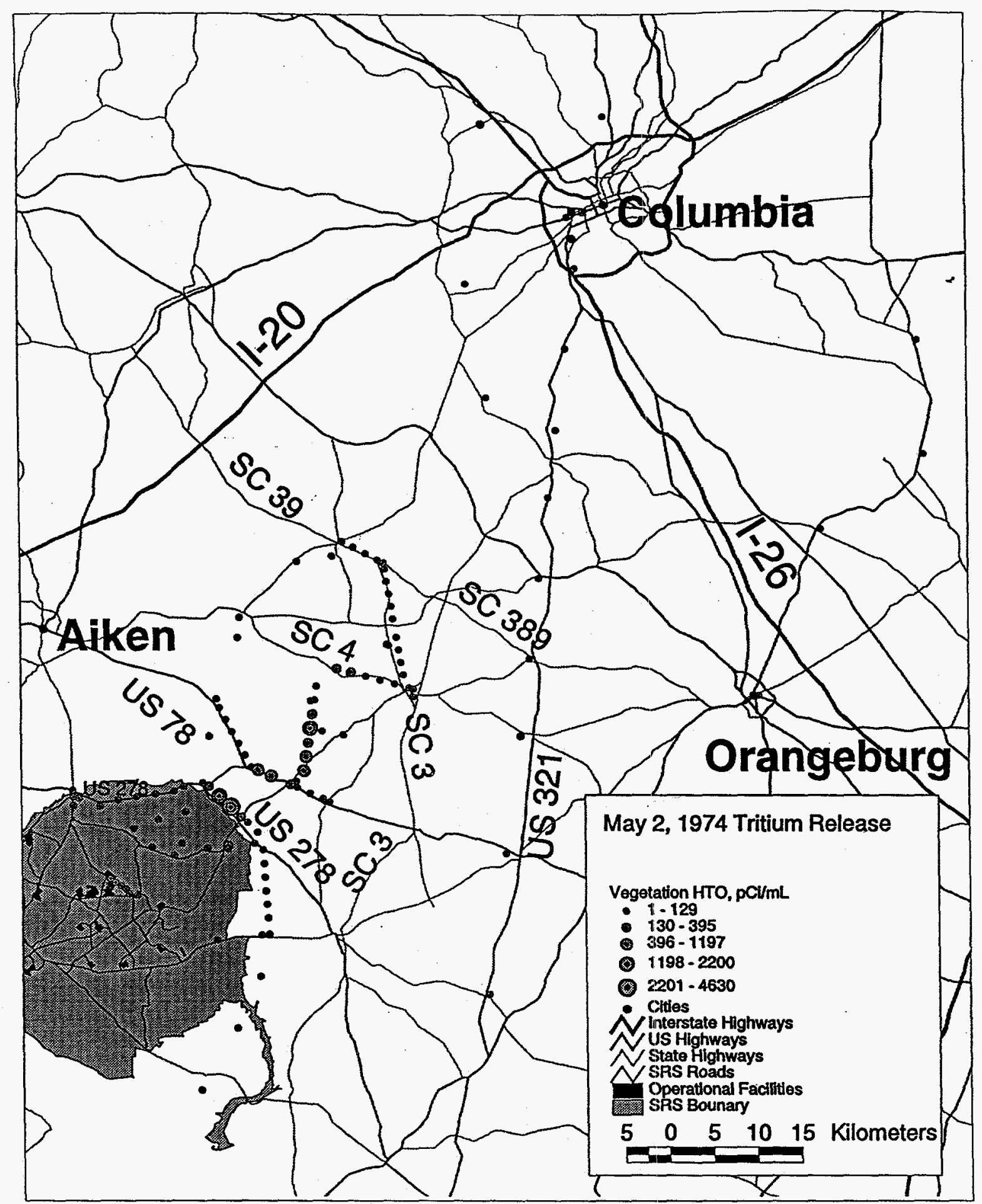

Figure A-7 Vegetative sampling locations following the tritium release of May 2, 1974. 


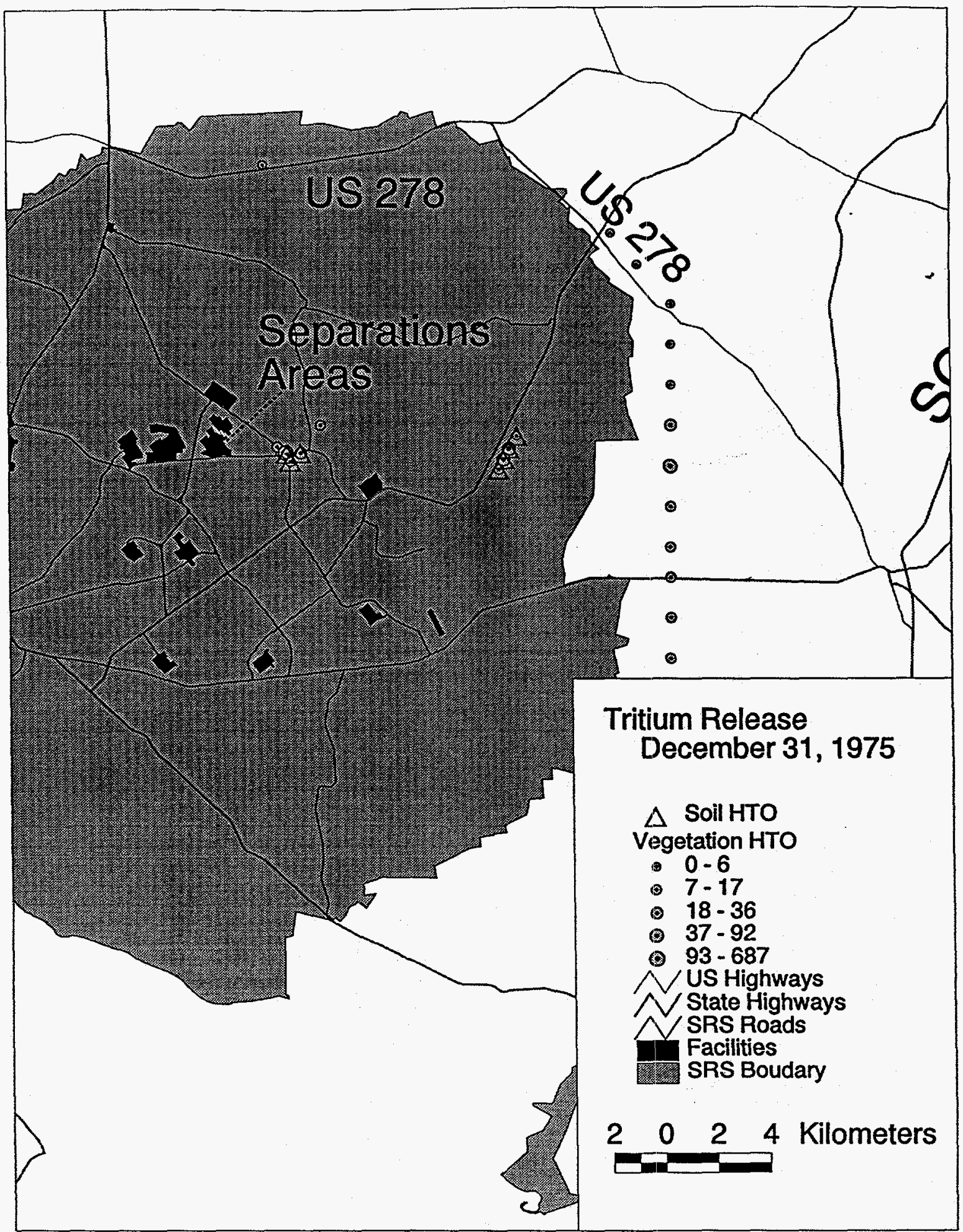

Figure A-8 Vegetative sampling locations following the tritium release of December 31, 1975. 


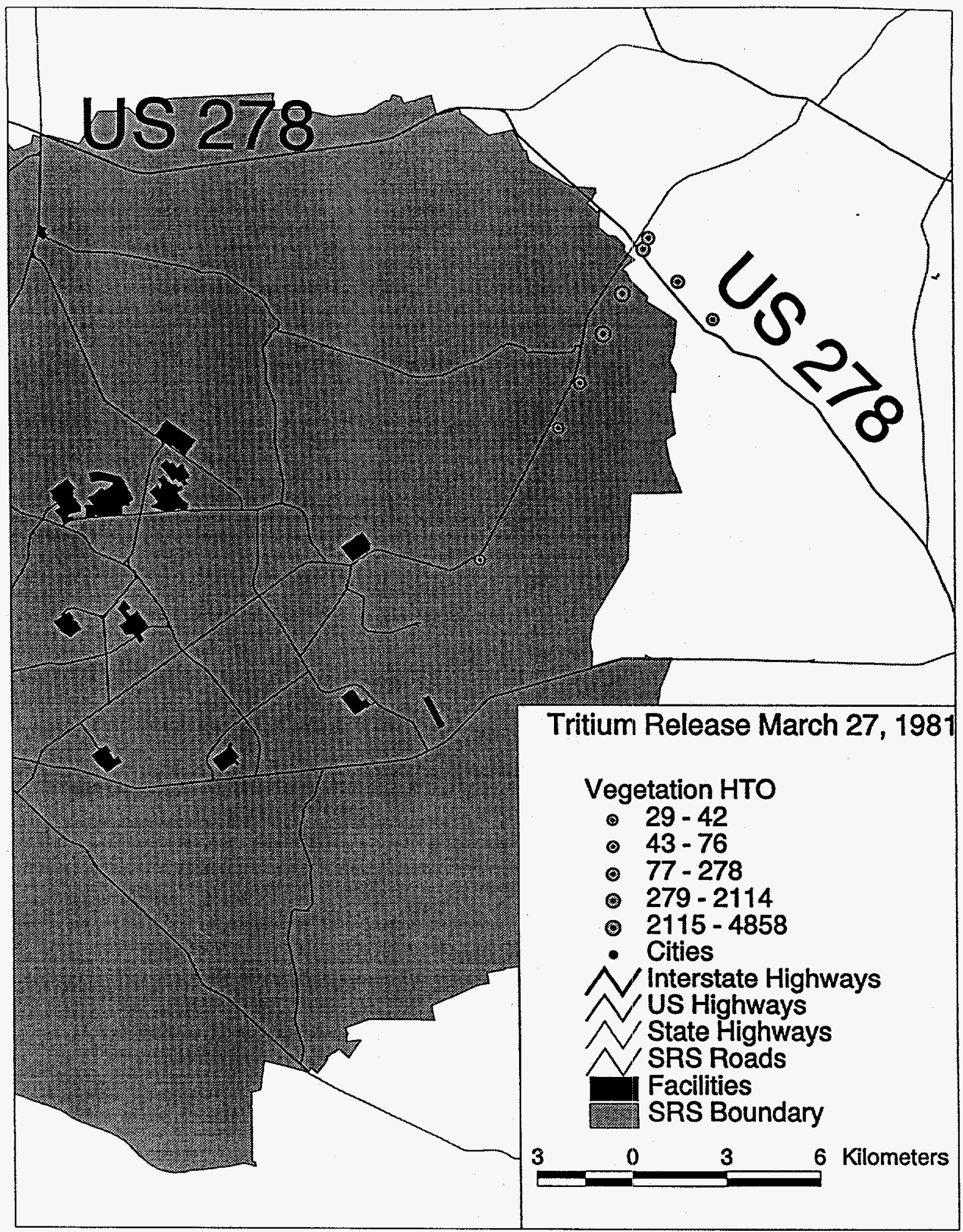

Figure A-9 Vegetative sampling locations following the tritium release of March 27, 1981. 


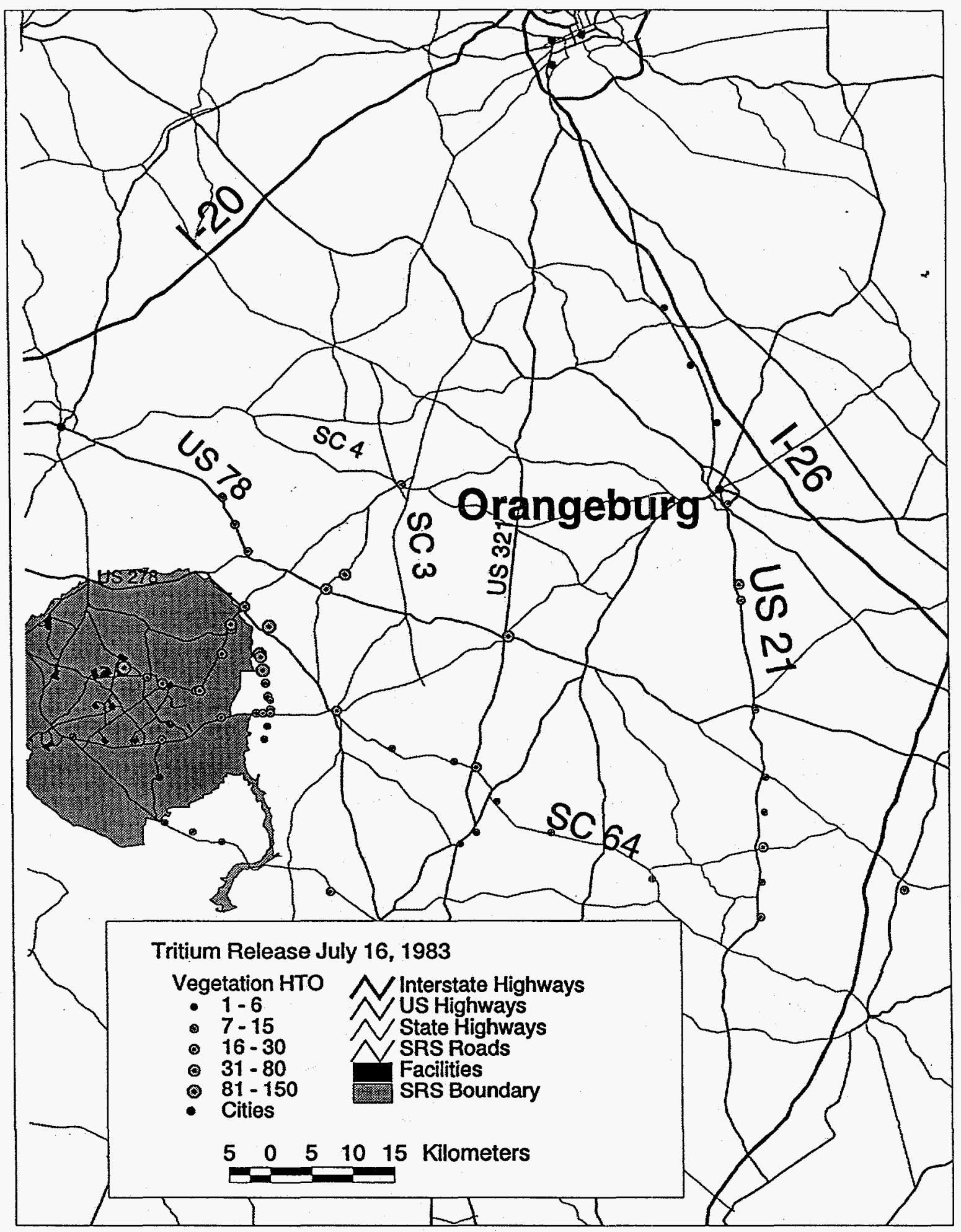

Figure A-10 Vegetative sampling locations following the tritium release of July $16,1983$. 


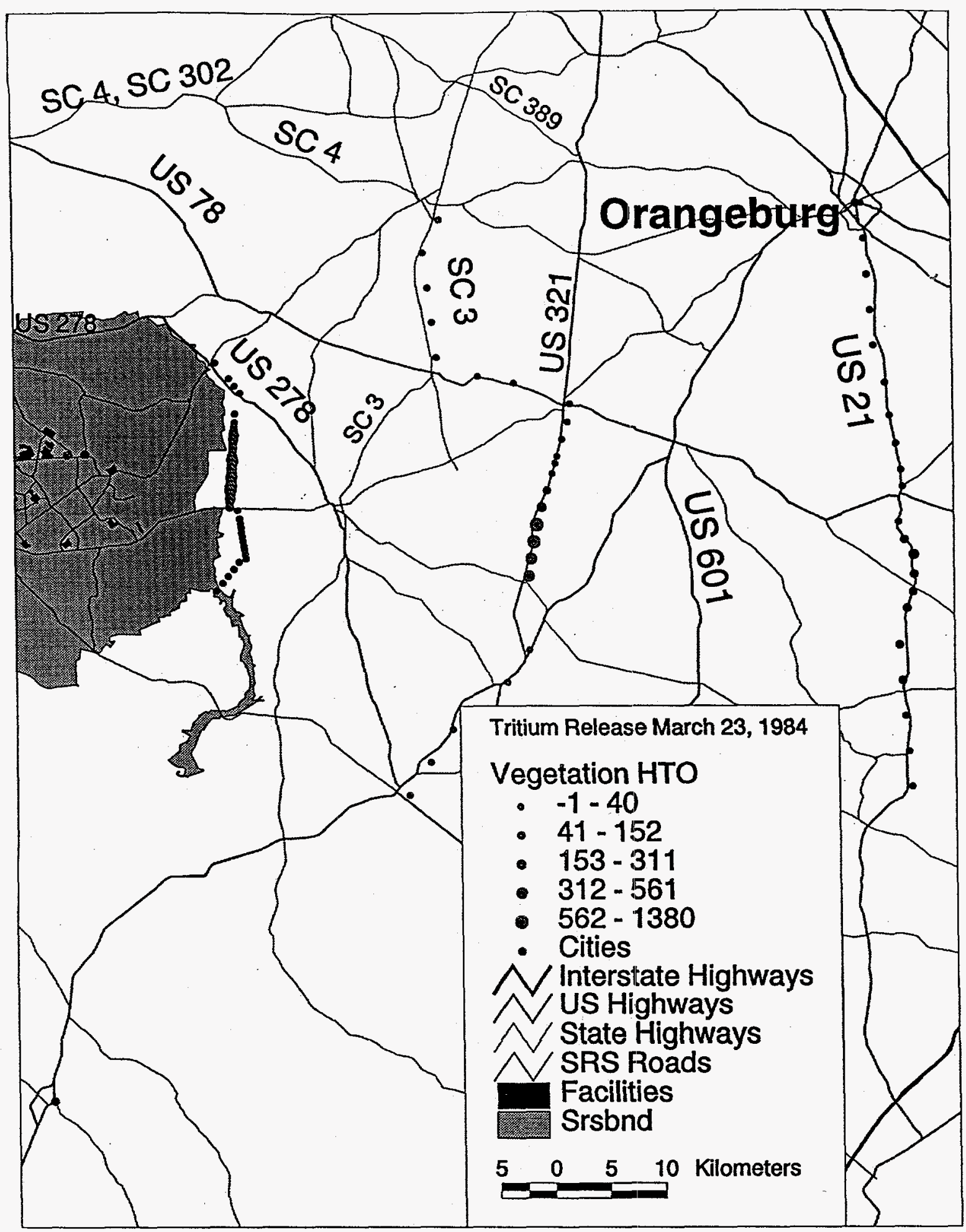

Figure A-11 Vegetative sampling locations following the tritium release of March 23, 1984. 


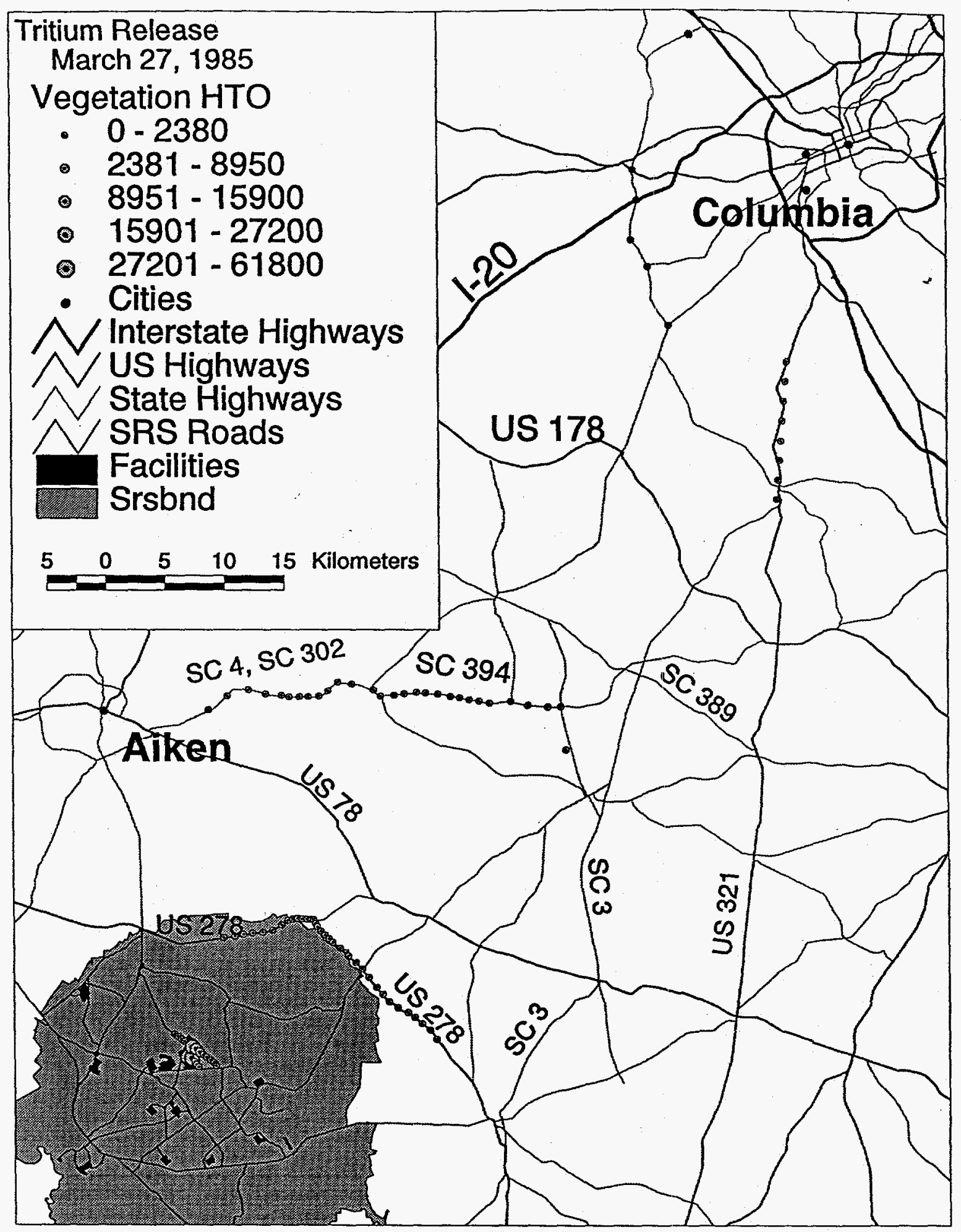

Figure A-12 Vegetative sampling locations following the tritium release of March 27, 1985. 


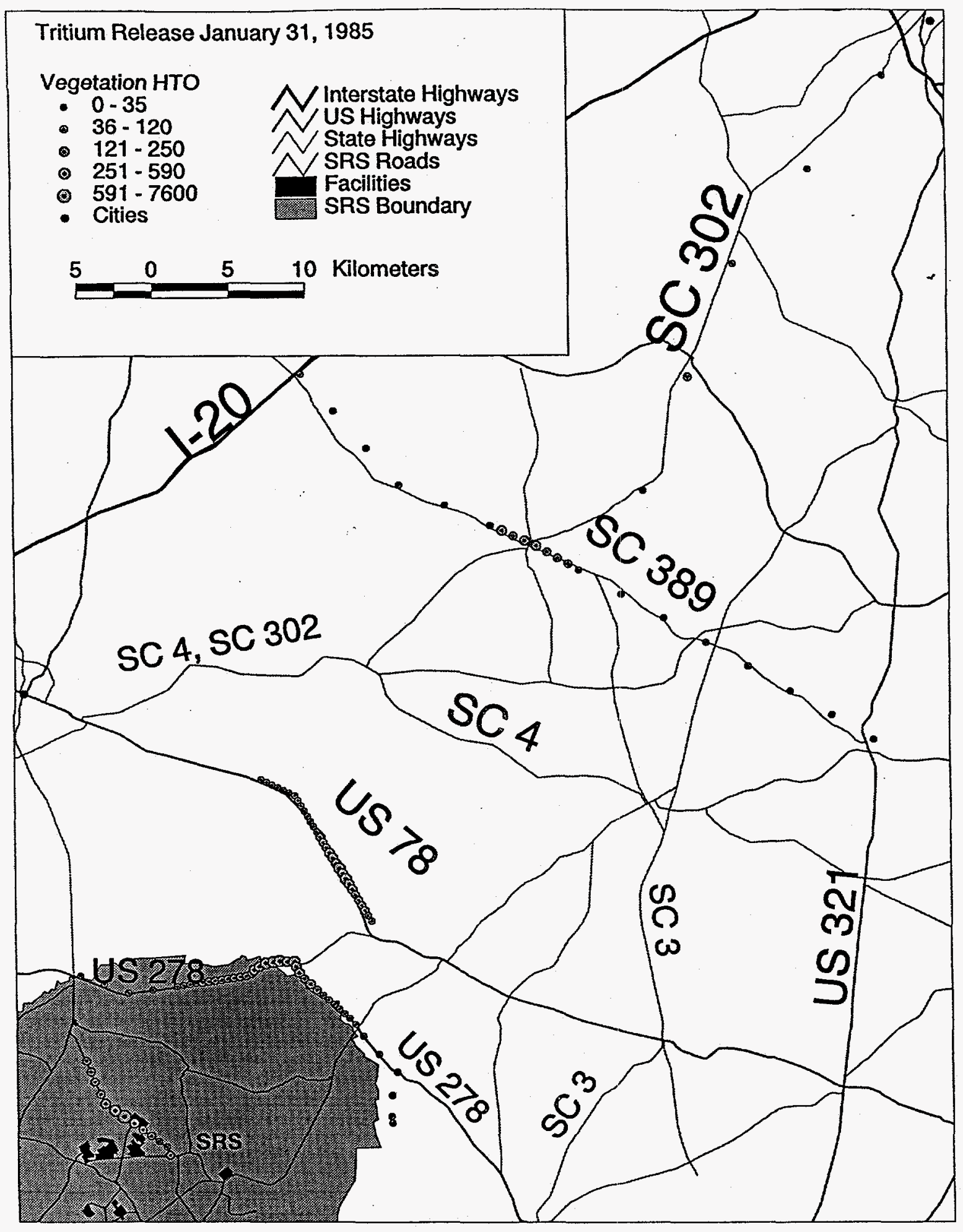

Figure A-13 Vegetative sampling locations following the tritium release of January 31, 1985. 


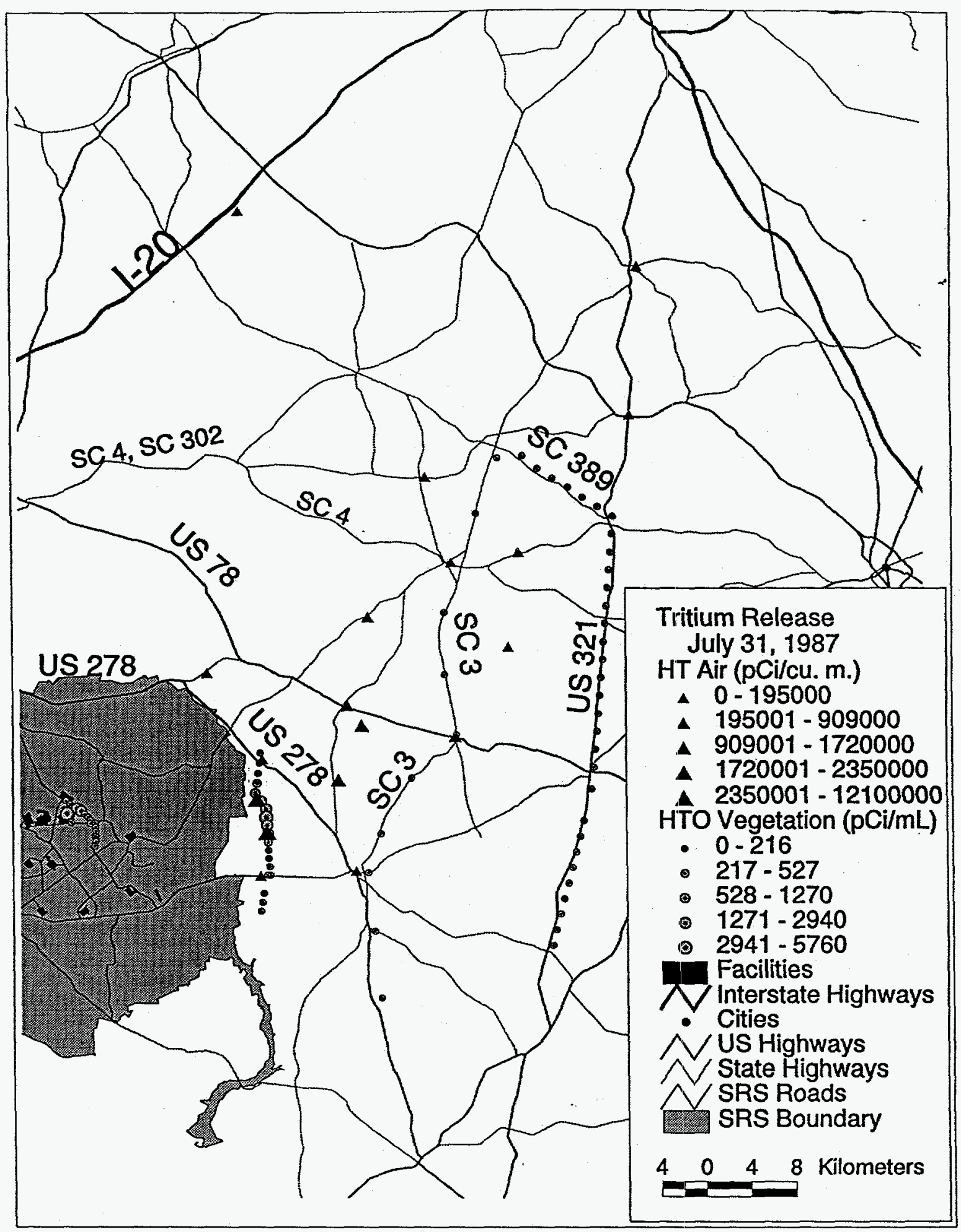

Figure A-14 Vegetative and air sampling locations following the tritium release of July 31, 1987. 